\title{
A randomized pilot trial evaluating safety and immunogenicity of recMAGE-A3 + AS15 immunotherapeutic administered by intramuscular versus intradermal/subcutaneous routes
}

\author{
Craig L Slingluff ${ }^{1 *}$, Gina R Petroni ${ }^{1}$, Walter C Olson ${ }^{1}$, Kimberly A Chianese-bullock${ }^{1}$, Kelly T Smith ${ }^{1}$, Mark E Smolkin ${ }^{1}$, \\ Nadedja Galeassi', William Grosh', Geoffrey Weiss', Kristy Scott', Ana Hornillo²
}

From Society for Immunotherapy of Cancer 29th Annual Meeting

National Harbor, MD, USA. 6-9 November 2014

\section{Introduction}

The recMAGE-A3 protein has been administered intramuscularly (IM) with immunostimulant AS15 as an experimental immunotherapeutic. AS15 contains 3-Odesacyl-4'-monophosphoryl lipid A (MPL), QS-21, CpG 7909 and liposome. This MAGE-A3/AS15 immunotherapeutic has not been studied for intradermal (ID) or subcutaneous (SC) use. A clinical trial (NCT01425749) was initiated to test the hypotheses that ID/SQ administration is safe and may induce $\mathrm{CD}^{+}$and $\mathrm{CD}^{+} \mathrm{T}$ cell responses to MAGE-A3.

\section{Patients and methods}

Twenty-five eligible patients with resected stage IIB-IV MAGE-A $3^{+}$melanoma were randomized to 2 arms, treated with MAGE-A3/AS15 Immunotherapeutic IM (Arm $A, n=13)$ or ID/SC (Arm B, $n=12)$. Adverse events (CTCAE 4) were recorded. Antibody (Ab) responses to MAGE-A3 protein were assessed by ELISA assay. $\mathrm{T}$ cell responses were assessed by flow cytometry after intracellular cytokine staining (ICS) for multifunctional $\mathrm{CD}_{4}^{+}$and $\mathrm{CD}^{+}$responses to overlapping MAGE-A3 peptides, assaying lymphocytes from peripheral blood (PBMC) and sentinel immunized node (SIN), after one in vitro stimulation.

\section{Results}

In both arms, the recMAGE-A3/AS15 immunotherapeutic was well-tolerated, with only one grade 3 treatment-related adverse event (hyperglycemia, Arm B), and no grade 4 or

${ }^{1}$ University of Virginia, Charlottesville, USA

Full list of author information is available at the end of the article
5 events. Grade 2 injection site reactions were observed in 10 patients in Arm A and 7 in Arm B (P > 0.3). Ab responses were detected in all patients, most with high titers persisting at least 6 months, without difference between arms. Preliminary T cell data are that multifunctional (IFNg and TNF $\alpha$ ) $\mathrm{CD} 4^{+} \mathrm{T}$ cell responses to MAGEA3 were detected in $64 \%$ of patients $(54 \%$ A; $75 \%$ B; Table 1). Multifunctional $\mathrm{CD} 8^{+} \mathrm{T}$ cell responses were evident in $20 \%$ of patients $(8 \% \mathrm{~A}, 33 \% \mathrm{~B})$. $\mathrm{CD} 4^{+}$responses were higher magnitude in SIN than in PBMC.

\section{Conclusion}

Safety profiles were comparable for ID/SC and IM administration of the MAGE-A3/AS15 immunotherapeutic, which induced high-titer $\mathrm{Ab}$, multifunctional $\mathrm{CD} 4^{+}$ Th1 responses, and $\mathrm{CD}^{+}$responses when administered by either route. Immune responses were more readily detected in the SIN than in PBMC. These pilot data

Table 1 Multifunctional (IFNg and TNF $\alpha$ ) T cell responses to MAGE-A3

\begin{tabular}{ccccccc}
\hline & \multicolumn{3}{c}{$\%$ of CD4+ T cells } & \multicolumn{3}{c}{ \% of CD8+ T cells } \\
\hline & \multicolumn{3}{c}{$(90 \% \mathrm{Cl})$} & & \multicolumn{3}{c}{$(90 \% \mathrm{Cl})$} \\
& SIN & PBMC & Either & SIN & PBMC & Either \\
Arm A & $31 \%$ & $31 \%$ & $54 \%$ & $0 \%$ & $8 \%$ & $8 \%$ \\
& $(11,58)$ & $(11,58)$ & $(29,78)$ & $(0,21)$ & $(0,32)$ & $(0,32)$ \\
Arm B & $64 \%$ & $50 \%$ & $75 \%$ & $18 \%$ & $25 \%$ & $33 \%$ \\
& $(35,86)$ & $(25,75)$ & $(47,93)$ & $(3,47)$ & $(7,53)$ & $(12,61)$ \\
\multirow{3}{*}{ Total } & $46 \%$ & $40 \%$ & $64 \%$ & $8 \%$ & $16 \%$ & $20 \%$ \\
& $(28,64)$ & $(24,58)$ & $(46,80)$ & $(2,24)$ & $(6,33)$ & $(8,38)$ \\
\hline
\end{tabular}


support further investigation of ID/SC immunization with antigen plus AS15 to support Th1 $\mathrm{CD} 4^{+}$responses and $\mathrm{CD}^{+}$responses. Production of Th1 cytokines IFNg and TNF $\alpha$ suggests the induced $\mathrm{CD} 4^{+}$responses may support $\mathrm{CD}^{+} \mathrm{T}$ cells. Other forms of antigen (e.g.: long peptides) may further support induction of $\mathrm{CD}^{+} \mathrm{T}$ cell responses in combination with AS15.

Funding source: GlaxoSmithKline Biologicals SA

\section{Authors' details}

${ }^{1}$ University of Virginia, Charlottesville, USA. ${ }^{2}$ Glaxo Smith Kline, Belgium.

Published: 6 November 2014

doi:10.1186/2051-1426-2-S3-P60

Cite this article as: Slingluff et al:: A randomized pilot trial evaluating safety and immunogenicity of recMAGE-A3 + AS15 immunotherapeutic administered by intramuscular versus intradermal/subcutaneous routes. Journal for ImmunoTherapy of Cancer 2014 2(Suppl 3):P60.

Submit your next manuscript to BioMed Central and take full advantage of:

- Convenient online submission

- Thorough peer review

- No space constraints or color figure charges

- Immediate publication on acceptance

- Inclusion in PubMed, CAS, Scopus and Google Scholar

- Research which is freely available for redistribution

Submit your manuscript at www.biomedcentral.com/submit 